\title{
Why Has the Border Effect in the Japanese Machinery Sectors Declined?: The Role of Business Networks in East Asian Machinery Trade
}

\author{
Kyoji Fukao \\ Hitotsubashi University \\ Toshihiro Okubo \\ Keio University
}

\begin{abstract}
This paper analyzes the impact of firm networks on Japan's national border effect. We estimate gravity equations using data on Japan's international and interregional trade in four machinery industries (electrical, general, precision and transportation machinery). The machinery sector is the most important manufacturing sector for exports and outward foreign direct investment (FDI) in Japan. By taking into account international as well as interregional firm networks, we find that ownership relations usually enhance exports from parent firms to establishment. Consequently we can explain 15\% (7\%, 1\% and $0.5 \%)$ of the decline in Japan's border effect from 1980 to 1995 in precision (transportation, general electrical) machinery sector by the increase of international networks.
\end{abstract}

- JEL Classification: F14, F17, F21, L14

- Keywords: Gravity Model, Border Effect, Firm Networks, Fragmentation

\footnotetext{
*Corresponding address: Kyoji Fukao; Institute of Economic Research, Hitotsubashi University, Naka 21, Kunitachi, Tokyo 186-8603 Japan, E-mail: k.fukao@srv.cc.hit-u.ac.jp. / Toshihiro Okubo; Keio University 2-15-45 Mita Minato-ku Tokyo, 108-8345, Japan. E-mail: okubo@econ.keio.ac.jp. @2011-Center for Economic Integration, Sejong Institution, Sejong University, All Rights Reserved.
} 


\section{Introduction}

As global trade barriers are being steadily dismantled and economies are becoming increasingly integrated, one would expect national borders to have a diminishing effect on international trade flows. Nevertheless, economists estimating gravity models to examine trade flows find that international borders continue to matter. McCallum (1995), for example, found that trade between Canada's different provinces was twenty-two times as large as trade between the provinces and different states of the USA. Several subsequent studies have reestimated the U.S.Canadian border effect using many kinds of approach, while others have applied the idea to many other countries and discuss the presence of the national border effect. ${ }^{1}$ Although many studies measure the border effect with different values, the magnitude of border effects depends strongly on the estimation model and methodology (Dias, 2011). Thus this paper is not aimed at making a direct comparison in the value of border effects with existing studies using a new methodology. This paper investigates reasons for the over-time decline of border effect rather than measuring the level of border effect. In precise we study whether the decline of border effect can be explained by business networks.

The Japanese national border effect, the focus of this paper, is estimated over the period 1960 to 1990 in Okubo (2004) who found a substantial decline of the border effect particularly in the 1960s and 70s. ${ }^{2}$ The border effect in the early postwar period was fairly high but lowered significantly during the 1980s and $90 \mathrm{~s}$. He pointed out that one of the reasons for falling border effect in the 1980s and 1990s is that drastically increased Japanese foreign direct investment (FDI) drove intermediate inputs trade. In parallel, as Ahn, Fukao and Ito (2007) has shown, Japan's international division of labor with other East Asian countries has deepened significantly through the fragmentation of production processes and

\footnotetext{
${ }^{1}$ Recent research has reconsidered the border effect, Anderson and van Wincoop (2003), for example, developed a notion of a multilateral resistance term and then estimated this term using price data sets. Their results suggest that small countries tend to have a smaller border parameter than large countries. Santos Silva and Tenreyro (2006) used Monte Carlo simulations to overcome the problem of inconsistent coefficients inherent in log linear estimations. Dias (2011) made comparison by re-evaluating the border effect by several methodologies. As a result of a non-linear estimation method, he found much smaller effect than in McCollum's case.

${ }^{2}$ Okubo (2004), which is our benchmark study, estimated the Japanese border effect using macro-data, i.e. all manufacturing case and all tradable goods case. As a result, trade in all goods between Japanese regions was ten times as large as trade between the Japanese region and foreign countries until the 1970s, but the border effect declined in the 1980s and 1990s.
} 
vertical intra-industry trade, particularly in the machinery sectors. A driving factor behind this trend has been a substantial increase in Japan's outward FDI in the machinery sectors during the 1980s and 1990s, spurring Japan's international trade in particular for intermediate goods. ${ }^{3}$

A number of studies have analyzed the relationship between Japan's FDI and the increases in her international trade. In particular FDI in machinery sectors has promoted Asian trade. Using industry level data on Japan's international trade and on exports and imports by Japanese firms' foreign affiliates, Fukao and Chung (1997) showed that increased FDI in Japan's machinery sectors toward Asia has contributed to re-imports and intermediate goods trade since around 1986. ${ }^{4}$ A more rigorous examination of the influence of Japan's FDI on its vertical intra-industry trade (VIIT) is provided by Fukao, Ishido and Ito (2003) who develop a model to capture the main determinants of VIIT that explicitly includes the role of FDI. ${ }^{5}$ Testing this model empirically, using data from the electrical machinery industry, they show that FDI in the electrical machinery sector does play a significant role in the rapid increase in VIIT in East Asia experienced in recent years.

Few empirical studies have measured how Japan's FDI lowers national border effects. ${ }^{6}$ Our paper follows on from Okubo (2004) and is aimed at discovering why the border effect lowered substantially in the 1980s and 1990s and whether Japanese firm networks and ownership relations through FDI promote trade, thus lowering the border effect. We estimate border effects in four machinery sectors by estimating gravity equations for Japan's interregional trade and trade between Japan's regions. In the estimation, we explicitly take account of inter-firm networks. We conduct separate gravity model estimations for four machinery industries: electrical, general, precision, and transportation machinery.

\footnotetext{
${ }^{3}$ Another possible explanation for the decline of the border effect is that reductions in Japan's tariff rates and nontariff barriers have increased Japan's foreign trade. However, reductions in Japan's tariff rates occurred mainly between 1960 and 1980, Japan's tariff rates were already very low in the 1990s (Okubo, 2004). Moreover, at least in the machinery industry, non-tariff barriers also seem to have been not particularly high in the 1980s and 1990s (Sazanami, Urata and Kawai, 1995; Fukao, Kataoka and Kuno, 2003). On Japanese trade impediments, see Lawrence (1987).

${ }^{4}$ Re-imports are defined as imports from Japanese affiliates abroad. See Lipsey, Ramstetter and Blomström (2000) for more details about Japan's re-imports.

${ }^{5}$ Okubo (2007) found that Japanese VIIT in Asia is driven by trade related to Japanese FDI.

${ }^{6}$ One study examining the relationship between Japan's outward FDI and imports using a gravity type equation is that by Eaton and Tamura (1994), which does so only at the macro level. Greaney (2005) studied the impact of firm networks of US-owned firms on international trade flows using the Gravity equation, although it does not focus on national border effects.
} 


\section{A. Some stylized facts for Japanese machinery sectors}

Japanese machinery sectors in the last decade are a useful setting in which to study the impact of networks on national border effect. Our reasons for focusing on these four machinery industries stem from many stylized facts on their sectoral characteristics and are as follows:

(a) Most of Japan's FDI activities in the manufacturing sector have been concentrated in the machinery industry. According to the JIP Database in 2006 Japanese affiliates abroad in the machinery industry employed 2.1 million workers, accounting for $54 \%$ of all the workers employed by Japanese affiliates abroad in 2002. ${ }^{7}$ Furthermore, FDI in machinery sectors is geographically concentrated in Asian countries. According to The Survey on Overseas Business Activities, METI (Kaigai Jigyou Katsudou Kihon Chosa), over $70 \%$ of employees by Japanese foreign affiliates in machinery sectors worked in Asia over recent decades.

(b) The machinery industry is Japan's most important export sector, accounting for $76 \%$ of Japan's total goods exports in 2004. At the same time, the share of machinery imports in Japan's total imports has increased dramatically in recent years from $10 \%$ in 1985 to $32 \%$ in 2004 (JIP Database 2006).

(c) Theoretical studies in the field of organizational economics as well as a number of empirical studies have shown that firms tend to choose intra-firm transactions in the case of high-tech and R\&D-intensive products. ${ }^{8}$ The machinery industry is one of the most R\&D-intensive industries, accounting for a full $65 \%$ of all R\&D expenditure in the manufacturing sector in Japan in 1995 (JIP Database 2003). ${ }^{9}$ Therefore, we expect that business networks play an important role in this sector.

(d) Even within the machinery sector, there are large differences in the patterns of VIIT and outsourcing between different industries, such as between the electrical and transportation machinery industries. The trade and FDI patterns of Japan's machinery sector are presented in Figure 1, which shows that in the case of the electrical and the transportation machinery industries, production by Japanese affiliates abroad has surpassed exports from Japan. In order to analyze the effect of inter-firm networks on international trade in machinery industries, it is therefore

\footnotetext{
${ }^{7}$ The JIP Database 2006 is downloadable at: <http://www.rieti.go.jp/en/database/d05.html>.

${ }^{8}$ For a comprehensive survey of this issue, see Itoh (2006).

${ }^{9}$ The JIP Database 2003 is downloadable at: <http://www.esri.go.jp/en/archive/bun/abstract/bun170 index-e.html >. Machinery sectors account for $64.9 \%$ (63.4\%) of the total R\&D expenditure in manufacturing in 1995 (1985).
} 
necessary to look at trade flows at a relatively disaggregated level.

(e) Machinery industries are the main sectors of Asian fragmentation. As shown in Baldwin (2008) and Ando and Kimura (2005), machinery sectors are parts and components intensive and thus geographically separable in terms of the production process, which allow "task trade" across countries ("the unbundling of tasks") by creating business networks. The production process is thus diversified across regions and countries and promotes Asian trade. One of the largest amount of tradable goods in the current Asian trade is parts and components in machinery sectors. According to The Survey on Overseas Business Activities, export ratios in total sales in Japanese overseas affiliates account for 40 to $50 \%$ in machinery sectors, which is substantially higher than any other manufacturing sector (20 to 30 $\%) .{ }^{10}$ This indicates that the main purpose of FDI in machinery sectors is a part of the production process rather than local sales in host countries.

As we turn our attention from the international to the interregional situation, it is important to emphasize some additional stylized facts. Business networks in machinery industries seem to play an important role, not only in international trade but also in Japan's intra-national trade. Intermediate input trade between different regions of Japan is fairly high in the machinery sector. We measure this using an interregional outsourcing index which is defined as the ratio of the intermediate input imports in a certain sector from the same sector from all other Japanese regions relative to final goods production of that sector in that region. ${ }^{11}$ The data are taken from the Input-Output (I-O) Tables of Interregional Relations (Chiiki-kan Sangyo Renkan Hyo). The averages across the nine regions of Japan of the outsourcing index for each manufacturing sector for 1995 are shown in Figure 2. As can be seen, the outsourcing index is relatively high in textiles and in the machinery sectors indicating active interregional intermediate input trade. Among machinery sectors, the index is particularly high at more than 0.12 in electrical and transport machinery. The high degree of interregional intermediate input trade in the machinery industries reflects the fact that these are parts-and-component-

\footnotetext{
${ }^{10}$ Export (to third countries or Japan) ratio of total sales in Japanese foreign affiliates in 2005 are $44.8 \%$ in industry machinery and equipment, $43.1 \%$ in electronic and other electric equipment, $43.6 \%$ in computers and electronic products and $41.1 \%$ in transportation equipment, whereas other sectors are much smaller percentage, e.g. $23.4 \%$ in food and kindred products and $32.5 \%$ in chemicals and allied products.

${ }^{11}$ The index used here is an index of "narrow" outsourcing and is an application to interregional outsourcing of the type of index discussed in the literature on international outsourcing. See Feenstra and Hanson (1999) and Ekholm and Hakkala (2006).
} 
Figure 1. Japan's trade and foreign direct investment: machinery sector, 1991-2000.
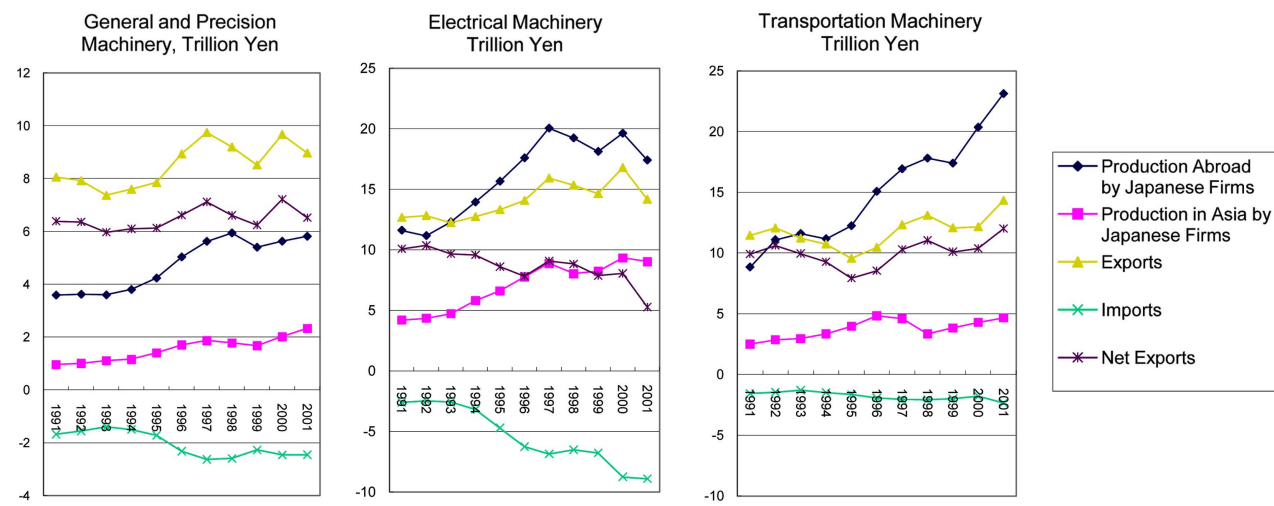

Sources : Economic and Social Research Institute, Cabinet Office, Government of Japan, Annual Report on National Accounts 2002; Economic Planning Agency, Government of Japan, Annual Report on National Accounts 2000.

Figure 2. Outsorcing index.

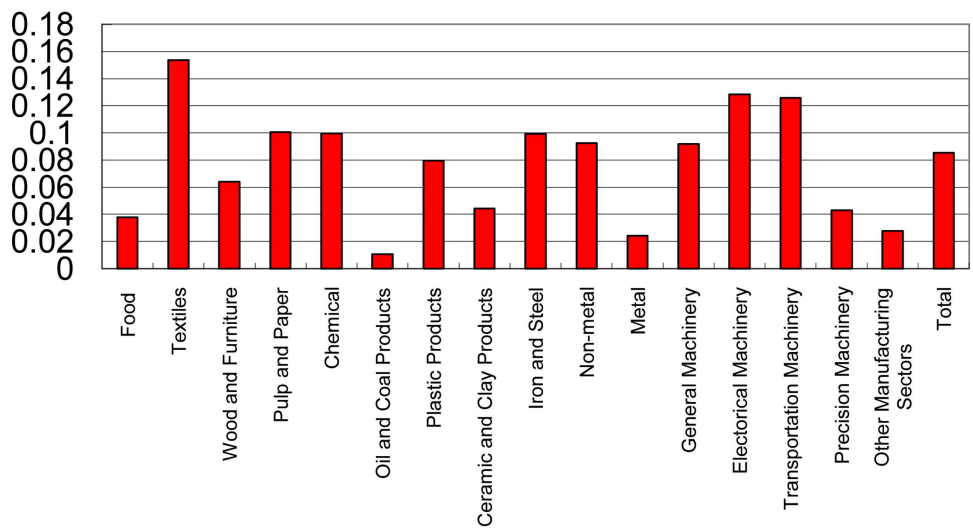

Source : MITI, Input-Output Tables of Interregional Relations (Chiiki-kan Sangyo Renkan Hyo) 1995.

intensive industries.

As shown by Fukao and Yue (1997), who focus their attention on firm location in the electrical machinery sector across Japanese regions, these industries tend to divide production processes into discrete steps, relocating labor-intensive processes to rural areas and maintaining their headquarters and high-tech process in big cities in the 1980s and 1990s. The fragmentation of production within Japan has led to 
increased interregional trade, in particular there has been increased intermediate goods and intra-firm trade ("task trade"). In this paper we compare the impacts of business networks on international trade with the impacts of business networks on intra-national trade.

These stylized facts tell us that it is worthwhile to focus on Japanese machinery sectors to study the impact of firm networks on Japan's national border. The remainder of the paper is organized as follows. Section II presents our empirical strategy, results and discussion. Finally, Section III summarizes the main findings of this paper.

\section{Econometric Analysis}

\section{A. Data}

To estimate the national border effect we use international trade in each of eight Japanese regions as well as interregional trade between Japanese regions. The interregional trade data are taken from the Input-Output (I-O) Tables of Interregional Relations (Chiiki-kan Sangyo Renkan Hyo). ${ }^{12}$ The drawback of our source for data regarding interregional trade is that the international trade data in the I-O tables are available only at the national level. There are no statistics on each region's bilateral trade with foreign countries. As a result we had to estimate this data, using the following methodology: first, we calculated each region's share in Japan's total imports and exports for each industry in the I-O tables. Next, we multiplied Japan's bilateral international trade in each industry with each region's trade share. We obtained data on Japan's international trade from World Trade Flows 1980-1997 (the Center for International Data, University of California, Davis). ${ }^{13}$ Figure 3 shows the share of international trade in the total trade of the eight Japanese regions for each industry. The denominator of each value is the sum of the eight regions' imports from (exports to) all foreign countries and all the other regions. The numerator is the sum of the eight regions' imports from (exports to) all foreign countries. The share of international imports in total imports of the

\footnotetext{
${ }^{12}$ The interregional I-O tables are published by the Ministry of Economy, Trade and Industry (MITI) every five years and cover all industries at the 2-digit level divided into nine Japanese regions: Hokkaido, Tohoku, Kanto, Chubu, Kinki, Chugoku, Shikoku, Kyushu, and Okinawa. Since Okinawa's economy is very small in comparison with the other regions and the production of machinery in Okinawa is negligible, we exclude Okinawa and analyze the eight remaining regions.

${ }^{13}$ See Appendix Table B for the list of foreign countries.
} 
Figure 3. Share of international trade in Japanese regions' total trade: by industry
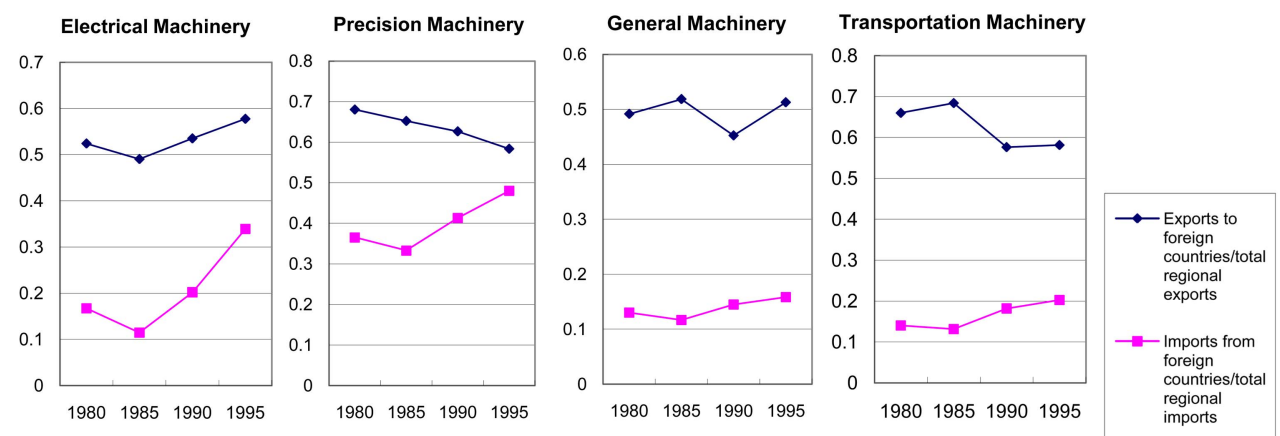

eight regions increased in all four industries during 1980-1995 and was especially large in the electrical and the precision machinery industries. In contrast, the share of international exports in total exports of the eight regions declined slightly in the transportation and the precision machinery industries.

Our data is also hindered by the fact that price indexes are not available in the interregional I-O table and for many Asian countries that are major trading partners of the Japanese machinery industries. Imputed price indexes have been used in recent studies employing gravity equations to estimate multilateral resistance (see Anderson and van Wincoop 2003). However, because of the lack of price data, we employ an alternative method of the origin-destination country fixed effect estimation (Rose and van Wincoop, 2003; Baldwin and Taglioni, 2006), as described below in detail.

We measure the size of Japanese firms' networks in a certain industry, which connect Japan with the same industry in a foreign country, by the number of Japanese affiliates in the same industry in that country, which we call these international firm networks. Similarly, we measure foreign countries' network links with Japan in a particular industry by using the number of those countries' affiliates in Japan in the same industry. We obtain this data from various issues of the following MITI publications: the Basic Survey of Overseas Business Activities (Kaigai Jigyo Katsudo Kihon Chosa), the Survey on Trends of Japan's Business Activities Abroad (Kaigai Jigyo Katsudo Doko Chosa) and the Report on Trends of Business Activities by Japanese Subsidiaries of Foreign Firms (Gaishikei Kigyo no Doko). Figure 4 shows firms' network linkages between Japan and foreign countries. The number of foreign affiliates owned by Japanese firms increased very 
Figure 4. Firms' network linkages between Japan and foreign countries: by industry

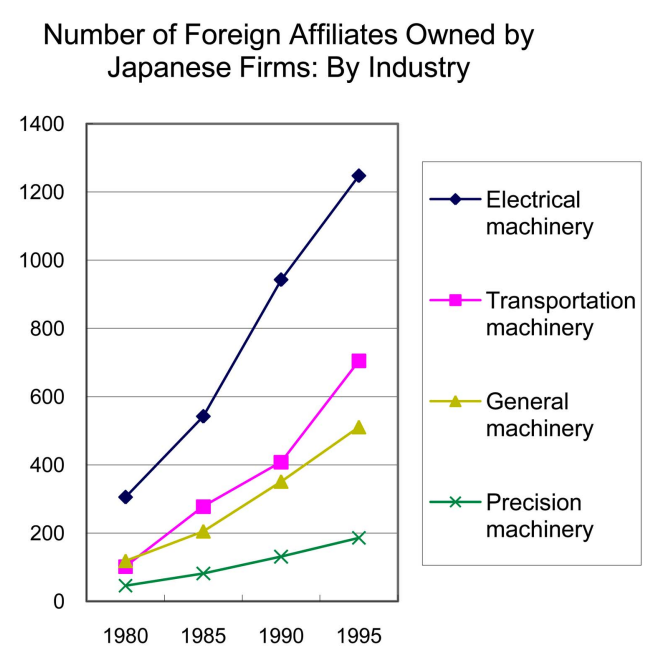
Number of Japanese Affiliates Owned by Foreign Firms: By Industry

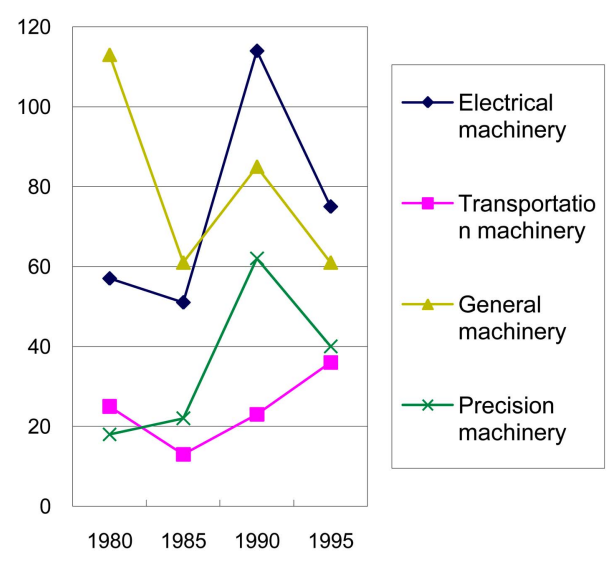

rapidly during 1980-1995. In contrast, the number of foreign firms' affiliates in Japan more or less stagnated.

No statistics on Japanese regions' bilateral inward and outward direct investment relationships with foreign countries at the industry level are available. Hence we had to estimate this data by assuming that all establishments have an equal probability of having direct investment relationships. We first calculate the share of the establishments located in each region in total Japan, for this we use the number of establishments with more than 30 employees in each region in each sector for every year, the data are taken from the Census of Manufactures (Kogyo Toukei Hyo) of MITI. Then the total Japanese number of inward and outward direct investments, mentioned above, is weighted by the regional share of establishments. The result is the inward and outward direct investment in each Japanese region.

Turning to domestic network linkages, we directly measure the size of firms' networks in a certain industry in region $i$, which connect this region with the same industry in region $j$, by the number of establishments owned by firms in region $i$ and located in region $j$ (interregional networks). The data are taken from the Special Aggregation Tables of the Establishment and Enterprise Census (Jigyosho Kigyo Tokei Chosa, Tokubetsu Shukei Hyo) of the Ministry of Public Management, Home Affairs, Posts and Telecommunications. The data are available only for 1991. However firms' interregional networks in Japan remained 
unchanged during the period 1980-1995 and thus we use the same data for the whole period. $^{14}$

\section{B. Multilateral Resistance}

A recent advancement in the estimation of the gravity equation is the recognition of "multilateral resistance" as proposed by Anderson and van Wincoop (2003). They suggest that measuring the border effect should take account of multilateral resistance so as to better reflect trade theory in the formulation of the gravity equation:

$$
\operatorname{Trade}_{i j}=\left(Y_{i} Y_{j}\right)\left(\frac{T_{i j}}{P_{i} P_{j}}\right)^{1-\sigma} ; T_{i j}=b d_{i j}^{\rho}
$$

where GDPs $(Y \mathrm{~s})$ and distance $(d)$ appear in the same manner as in the standard gravity model and the novelty is the price index, $P$ (multilateral resistance). ${ }^{15}$ Bilateral trade is influenced by the relative trade resistance denoted as $\left(\mathrm{T}_{i j} / P_{i} P_{j}\right)$ where $b$ is the border dummy. A small country has a higher level of multilateral resistance (price index) and vice versa, because the small country is more likely to be directly affected by increased trade barriers in foreign countries. It follows that the higher multilateral resistance in small countries when compared with large countries decreases the relative trade resistance and thus their bilateral trade decreases less. In terms of the border dummy this gravity equation raises the border effect in a relatively large country with lower multilateral resistance but lowers the border effect in a relatively small country.

Since price indices for Japanese regions are not available we replace them with country dummies as in Rose and van Wincoop (2000), Baldwin and Taglioni (2006) and Martin et al. (2007) generalized by Anderson and van Wincoop's (2003) methodology. The estimated equation is written as

$$
\log \left(T_{R A D E} E_{i, j}\right)=\alpha_{0}+\alpha_{1} \log \left(D I S_{i, j}\right)+\alpha_{2} \text { BORDUM }_{i, j}+\sum^{R, C} \alpha_{\mathrm{ik}} C_{i k}+\sum^{R, C} \alpha_{\mathrm{jk}} C_{j k}+\varepsilon_{i, j}
$$

where Trade refers to trade between country or region $i$ and $j$. DIS refers to

\footnotetext{
${ }^{14}$ According to various issues of the Establishment and Enterprise Census, the number of manufacturing establishments in the years 1981, 1986, 1991, and 1996 was 873,000, 875,000, 857,000, and 772,000 respectively. Therefore, it seems that the number of firms' interregional linkages in Japan has stagnated or slightly declined in the period. On this issue, see Tomiura (2003).

${ }^{15}$ Note that $\sigma$ is the elasticity of substitution between varieties in the CES function.
} 
Table 1. Border Effect

\begin{tabular}{|c|c|c|c|c|c|c|c|c|c|}
\hline \multirow[t]{2}{*}{ Electrical } & \multirow{2}{*}{$\frac{\text { year }}{\text { variables }}$} & \multicolumn{2}{|c|}{1980} & \multicolumn{2}{|c|}{1985} & \multicolumn{2}{|c|}{1990} & \multicolumn{2}{|c|}{1995} \\
\hline & & coefficients & t-values & coefficients & t-values & coefficients & t-values & coefficients & t-values \\
\hline & Dis & -0.747 & $-2.34 * *$ & -0.671 & $-1.73 *$ & -0.614 & $-1.84 *$ & 0.017 & 0.04 \\
\hline & Border & 6.405 & $6.27 * *$ & 2.279 & $1.83 *$ & 0.226 & 0.21 & 2.936 & $2.4 * *$ \\
\hline & Number of Observation & 808 & & 832 & & 824 & & 832 & \\
\hline & $\mathrm{F}$ & 84.46 & & 47.37 & & 65.49 & & 46.11 & \\
\hline & R-squared & 0.8652 & & 0.7866 & & 0.8349 & & 0.782 & \\
\hline & variables & coefficients & t-values & coefficients & t-values & coefficients & t-values & coefficients & t-values \\
\hline & Dis & -0.492 & $-1.67 *$ & -0.541 & $-1.69 *$ & -0.561 & $-1.69 *$ & -0.442 & -1.04 \\
\hline & Border & 8.552 & $9.08 * *$ & 2.459 & $2.4 * *$ & 1.611 & 1.51 & 2.278 & $1.67 *$ \\
\hline & Number of Observation & 816 & & 816 & & 840 & & 840 & \\
\hline & $\mathrm{F}$ & 88.22 & & 66.05 & & 65.1 & & 31.16 & \\
\hline & R-squared & 0.869 & & 0.835 & & 0.8337 & & 0.7059 & \\
\hline \multirow[t]{6}{*}{ Precision } & year & \multicolumn{2}{|c|}{1980} & \multicolumn{2}{|c|}{1985} & \multicolumn{2}{|c|}{1990} & \multicolumn{2}{|c|}{1995} \\
\hline & Dis & -1.329 & $-4.94 * *$ & -1.341 & $-4.62 * *$ & -1.248 & $-4.2 * *$ & -0.722 & -0.9 \\
\hline & Border & 2.521 & $2.93 * *$ & -1.071 & -1.15 & -2.031 & $-2.13 * *$ & -1.778 & -0.69 \\
\hline & Number of Observation & 776 & & 824 & & 816 & & 816 & \\
\hline & $\mathrm{F}$ & 59.62 & & 48.11 & & 56.86 & & 8.45 & \\
\hline & R-squared & 0.817 & & 0.7909 & & 0.8161 & & 0.3973 & \\
\hline \multirow[t]{7}{*}{ Transport } & year & \multicolumn{2}{|c|}{1980} & \multicolumn{2}{|c|}{1985} & \multicolumn{2}{|c|}{1990} & \multicolumn{2}{|c|}{1995} \\
\hline & variables & coefficients & t-values & coefficients & t-values & coefficients & t-values & coefficients & t-values \\
\hline & Dis & -0.763 & $-2.11 * *$ & -0.797 & $-1.9 *$ & -0.751 & $-2.03 * *$ & -0.747 & -1.47 \\
\hline & Border & 7.211 & $6.21 * *$ & 1.327 & 0.98 & 0.503 & 0.43 & 0.310 & 0.19 \\
\hline & Number of Observation & 832 & & 864 & & 768 & & 848 & \\
\hline & $\mathrm{F}$ & 50.39 & & 36.89 & & 50.25 & & 20.51 & \\
\hline & R-squared & 0.7908 & & 0.7406 & & 0.8072 & & 0.6099 & \\
\hline
\end{tabular}

** Significance at $5 \%$ level * Significance at $10 \%$ level 
geographical distance between two countries or regions. The border dummy, BORDUM, takes a value of one for trade between Japanese regions and otherwise takes a value of zero. $C_{i k}$ denotes an origin country dummy, if country or region $k$ is an exporter $(k=i), \mathrm{C}_{i k}$ takes value of unity. $\mathrm{C}_{j k}$ denotes an origin country dummy, if country or region $k$ is an importer $(k=j), \mathrm{C}_{j k}$ takes value of unity. We use OLS regression in each sector and each year.

Table 1 reports the result. The distance parameter is significantly negative in many cases and the magnitude of the coefficient declines in all four sectors, this is in part due to trade cost reductions due to globalization. The border effect tends to be significantly positive and generally declines over time in each sector with some fluctuations. In particular, all sectors in 1980 experience substantially higher border effects, while other years have much lower border effects. This result is almost consistent with the aggregated manufacturing case as shown in Okubo (2004). Here we note that the level of border effect is different across econometric methods as discussed in Dias (2011). Also, we have to note that the level of border effect is influenced by many several factors such as culture and language barriers.

\section{Network effect}

We now estimate the impact of firm networks on trade. As we discussed in section I, Japanese FDI in machinery sectors is geographically concentrated in Asia and is a vertical type of FDI rather than horizontal, aimed at mass-production or labor intensive production processes in lower wage countries and thus promotes intermediate goods trade between Japan and host countries. Thus we can specify the estimation equation by adding network variables to estimation equation (2).

$$
\begin{gathered}
\log \left(\text { TRADE }_{i, j}\right)=\alpha_{0}+\alpha_{1} \log \left(D_{i S_{i, j}}\right)+\alpha_{2} \text { BORDUM }_{i, j}+\alpha_{3} N P A A F W O_{i, j} \\
+\alpha_{4} \text { NAFPAWO }_{i, j}+\alpha_{5} \text { NPAAFJA }_{i, j}+\alpha_{6} \text { NAPPAJA }_{i, j}+\sum^{R, C} \alpha_{\mathrm{ik}} C_{i k}+\sum^{R, C} \alpha_{\mathrm{jk}} C_{j k}+\varepsilon_{i, j}
\end{gathered}
$$

where $N P A A F W O_{i, j}$ and $N A F P A W O_{i, j}$ denote variables for networks between Japan and foreign countries. $N P A A F W O_{i, j}$ denotes the number of cross-border ownership relations where the parent firm is located in exporting country (region) $i$ and the affiliate is located in importing country (region) $j$. Conversely, $N A F P A W O_{i, j}$ denotes the number of cross-border ownership relations where the parent firm is located in the importing country (region) $i$ and the affiliate is located in the exporting country (region) $j$. Similarly, $N A F P A J A_{i, j}$ and $N P A A F J A_{i, j}$ denote 
variables for networks among regions in Japan. We note that all variables take logarithmic form. ${ }^{16}$ The precise definitions of the four variables are as follows:

$N P A A F W O_{i, j}$ : the number of affiliates in country or region $j$ owned by Japanese firms located in region or country $i$, if $i \in R$ and $j \in C$.

$N A F P A W O_{i, j}$ : the number of affiliates in country or region $j$ owned by country or region $i$ firms, if $i \in C$ and $j \in R$.

$N P A A F W O_{i, j}=0$, if $i \in R$ and $j \in R$.

$N A F P A W O_{i, j}=N P A A F W O_{j, i}$

$N P A A F J A_{i, j}$ : the number of establishments in region $j$ owned by firms in region $i$, if $i \in R$ and $j \in R$.

$N P A A F J A_{i, j}=0$, if $i \in R$ and $j \in C$ or if $i \in C$ and $j \in R$.

$N A F P A J A_{i, j}=N P A A F J A_{j, i}$

Table 2 reports the results. All NPAAFWO parameters are significantly positive in all sectors. The same is true for all NPAAFJA parameters with the exception of some sectors in 1995. On the other hand, NAFPAWOs are likely to have a significantly negative impact in later years regardless of their much smaller magnitudes than the positive coefficients on NPAAFJAs. NAFPAJAs are vague in sign and are not statistically significant in many cases.

This finding implies that cross-border ownership relations usually enhance trade between the two regions (countries). In all four industries, the coefficients on $N P A A F W O$ are greater than the coefficients on NAFPAWO, implying that the creation of cross-border ownership relations increases "exports" from the location of parent firms to establishments between Japanese regions and foreign countries.

Likewise, the coefficients on NPAAFJA are likely to be greater than the coefficients on NAFPAJA, implying that the creation of domestic ownership relations increases interregional "exports" from the location of parent firms/ headquarters to their establishments/plants within Japan.

Comparing the estimation results of the border parameter decline in Tables 1 and 2, we find how large networks contribute to the decline of border effect. For example, in precision machinery sector the decline border in Table 2 is $15 \%$ smaller than the corresponding decline in Table $2(\{(2.639+1.196) / 2.639\} /$ $\{(2.521+1.778) / 2.521\}-1=-0.147)$. Thus we infer that we can explain $15 \%$ of the

\footnotetext{
${ }^{16}$ In order to take logarithmic forms we add 1 to each variable.
} 
Table 2. Network Effect Results

\begin{tabular}{|c|c|c|c|c|c|c|c|c|}
\hline \multicolumn{9}{|l|}{ Electrical } \\
\hline \multirow{2}{*}{$\begin{array}{l}\text { year } \\
\text { variables }\end{array}$} & \multicolumn{2}{|c|}{1980} & \multicolumn{2}{|c|}{1985} & \multicolumn{2}{|c|}{1990} & \multicolumn{2}{|c|}{1995} \\
\hline & coefficients & t-values & coefficients & t-values & coefficients & t-values & coefficients & t-values \\
\hline DIS & -0.072 & -0.22 & -0.153 & -0.38 & -0.212 & -0.6 & 0.296 & 0.73 \\
\hline Border & 6.898 & $7.05 * *$ & 2.690 & $2.23 * *$ & 0.532 & 0.51 & 3.117 & $2.58 * *$ \\
\hline NPAAFWO & 2.099 & $6.76 * *$ & 2.651 & $7.16 * *$ & 1.816 & $5.52 * *$ & 1.625 & $4.12 * *$ \\
\hline NAFPAWO & -0.085 & -0.27 & -0.363 & -0.98 & -0.620 & $-1.81 *$ & -1.490 & $-3.63 * *$ \\
\hline NAFPAWO & 0.757 & $4.67 * *$ & 0.554 & $2.78 * *$ & 0.446 & $2.58 * *$ & 0.303 & 1.52 \\
\hline Number of Observation & 808 & & 832 & & 824 & & 832 & \\
\hline $\mathrm{F}$ & 87.7 & & 48.63 & & 64.96 & & 45.3 & \\
\hline R-squared & 0.8776 & & 0.8023 & & 0.8434 & & 0.7908 & \\
\hline \multicolumn{9}{|l|}{ General } \\
\hline$\overline{\text { year }}$ & \multicolumn{2}{|c|}{1980} & \multicolumn{2}{|c|}{1985} & \multicolumn{2}{|c|}{1990} & \multicolumn{2}{|c|}{1995} \\
\hline variables & coefficients & t-values & coefficients & t-values & coefficients & t-values & coefficients & t-values \\
\hline DIS & -0.067 & -0.22 & -0.285 & -0.87 & -0.331 & -0.94 & -0.229 & -0.5 \\
\hline Border & 8.666 & $9.96 * *$ & 2.532 & $2.65 * *$ & 1.679 & 1.63 & 2.335 & $1.76 *$ \\
\hline NPAAFWO & 4.257 & $10.87 * *$ & 5.182 & $10.71 * *$ & 3.562 & $7.5 * *$ & 3.041 & $5.26 * *$ \\
\hline NAFPAWO & -1.409 & $-3.6 * *$ & -2.330 & $-4.64 * *$ & -1.358 & $-2.71 * *$ & -2.701 & $-4.52 * *$ \\
\hline NPAAFJA & 0.611 & $3.97 * *$ & 0.426 & $2.52 * *$ & 0.376 & $2.07 * *$ & 0.363 & 1.55 \\
\hline NAFPAWO & -0.053 & -0.35 & -0.068 & -0.4 & -0.064 & -0.35 & -0.099 & -0.42 \\
\hline Number of Observation & 816 & & 816 & & 840 & & 840 & \\
\hline $\mathrm{F}$ & 98.86 & & 73.2 & & 66.49 & & 31.64 & \\
\hline R-squared & 0.8889 & & 0.8577 & & 0.8459 & & 0.7232 & \\
\hline
\end{tabular}


Table 2. Network Effect Results (continued)

\begin{tabular}{|c|c|c|c|c|c|c|c|c|}
\hline \multicolumn{9}{|l|}{ Precision } \\
\hline \multirow{2}{*}{$\begin{array}{l}\text { year } \\
\text { variables }\end{array}$} & \multicolumn{2}{|c|}{1980} & \multicolumn{2}{|c|}{1985} & \multicolumn{2}{|c|}{1990} & \multicolumn{2}{|c|}{1995} \\
\hline & coefficients & t-values & coefficients & t-values & coefficients & t-values & coefficients & t-values \\
\hline DIS & -0.954 & $-3.66 * *$ & -1.014 & $-3.54 * *$ & -0.922 & $-3.13 * *$ & -0.261 & -0.3 \\
\hline Border & 2.639 & $3.25 * *$ & -0.959 & -1.07 & -1.898 & $-2.06 * *$ & -1.196 & -0.47 \\
\hline NPAAFWO & 2.072 & $4.51 * *$ & 2.220 & $4.61 * *$ & 2.216 & $4.55 * *$ & 3.820 & $4.9 * *$ \\
\hline NAFPAWO & 0.533 & 1.13 & 0.150 & 0.3 & 0.353 & 0.72 & -3.284 & $-3.93 * *$ \\
\hline NPAAFJA & 1.335 & $7.61 * *$ & 0.965 & $5 * *$ & 0.990 & $4.98 * *$ & 0.507 & 1.08 \\
\hline NAFPAWO & -0.256 & -1.46 & -0.023 & -0.12 & -0.052 & -0.26 & 0.045 & 0.1 \\
\hline Number of Observation & 776 & & 824 & & 816 & & 816 & \\
\hline $\mathrm{F}$ & 64.13 & & 49.74 & & 58.02 & & 9.02 & \\
\hline R-squared & 0.8384 & & 0.8075 & & 0.8294 & & 0.4305 & \\
\hline \multicolumn{9}{|l|}{ Transport } \\
\hline variables & coefficients & t-values & coefficients & t-values & coefficients & t-values & coefficients & t-values \\
\hline$\overline{\text { DIS }}$ & -0.313 & -0.78 & -0.272 & -0.6 & -0.305 & -0.75 & -0.186 & -0.34 \\
\hline Border & 7.762 & $6.67 * *$ & 1.969 & 1.5 & 1.039 & 0.88 & 0.981 & 0.61 \\
\hline NPAAFWO & 2.065 & $4.31 * *$ & 3.996 & $7.39 * *$ & 2.642 & $4.83 * *$ & 3.084 & $5.29 * *$ \\
\hline NAFPAWO & -0.006 & -0.01 & -1.529 & $-2.83 * *$ & -0.838 & $-1.67 *$ & -2.329 & $-3.71 * *$ \\
\hline NPAAFJA & 0.582 & $2.7 * *$ & 0.624 & $2.56 * *$ & 0.544 & $2.49 * *$ & 0.575 & $1.93 *$ \\
\hline NAFPAWO & -0.017 & -0.08 & 0.035 & 0.14 & 0.005 & 0.02 & 0.113 & 0.38 \\
\hline Number of Observation & 832 & & 864 & & 768 & & 848 & \\
\hline $\mathrm{F}$ & 48.92 & & 38.73 & & 49.46 & & 21.26 & \\
\hline R-squared & 0.7977 & & 0.7623 & & 0.8157 & & 0.6348 & \\
\hline
\end{tabular}

** Significance at 5\% level * Significance at $10 \%$ level 
decline in Japan's border effect by the spread of international networks. Likewise, $7 \%, 1 \%$ and $0.5 \%$ of the decline of border effect can be explained in the transport, general and electrical machinery sectors respectively.

\section{Discussion}

It is important to note that the endogeneity problem between firm networks, in particular FDI, and trade is often discussed. Many existing studies have discussed whether FDI promotes trade or active trade drives FDI. However, we think that the problem in our paper is not serious as long as we focus only on Japanese machinery sectors. As we mentioned in the discussion of several stylized facts and previous studies in section 1 Japanese overseas production and domestic production in machinery sectors are vertical FDI aimed at reducing production costs rather than horizontal FDI aimed at promoting foreign local sales. ${ }^{17}$ Thus the production process is fragmented and spread geographically with ownership relations. The creation of firm networks drives intermediate trade, although we admit some circular causality in which intermediate-input trade might trigger more FDI. In parallel, as Baldwin (2008) mentioned, Asian trade is fairly active in a very limited range of products such as machinery products and parts and components, which is driven by production fragmentation and FDI networks. ${ }^{18}$ For this reason, we use the simple gravity equations and add some network variables as independent variables.

Finally we discuss the limitations of our study, which hinge on data qualification and the weakness of the gravity equation. First, our border effect may not fully reflect trade costs.

Transportation costs and transaction costs do not always correspond to geographical distance (Anderson and van Wincoop, 2004; Balistreri and Hillberry, 2006). Intermediate input trade involves transactions costs that are different from transaction costs in final goods trade. The nature of such transaction costs is different. The issue of the gravity equation estimation which includes transaction costs is open to future research. Second, the nature of firm networks is not taken into account in our paper. Firm networks have heterogeneous features and functions due to differences in firm organization and sectoral characteristics. This topic is also open to future research.

\footnotetext{
${ }^{17}$ For example, firms first observe exports to large markets and then invest to sell more. Major trading partners attract FDI. This could often happen in the case of horizontal FDI (HFDI).

${ }^{18} \mathrm{He}$ called "Factory Asia" and raised an example of an assembly factory in Malaysia using many intermediate goods from other Asian countries such as Japan.
} 


\section{Conclusions}

This paper analyzed the causes of the decline in Japan's border effect in four machinery industries (electrical, general, precision, and transportation machinery) by estimating gravity equations for Japan's international and interregional trade. We obtained data on firms' networks from outward and inward FDI statistics and data from the Establishment and Enterprise Census. In the case of the estimation of the Gravity equation, we find that the border effect declined in all four industries over the period 1980-1995. When we add network variables, we find that ownership relations usually enhance trade between two regions (countries). This result implies that the creation of ownership relations leads to greater increases in the exports from the location of the parent firm to the location of the affiliate than the other way around. Likewise, the creation of domestic ownership relations leads to greater increases in the interregional "exports" from the location of the parent to the location of the establishments within Japan. Finally, we find that we can explain $15 \%(7 \%, 1 \%$ and $0.5 \%)$ of the decline in Japan's border effect from 1980 to 1990 in the precision (transportation, general and electrical) machinery sectors by the increase of international networks.

Finally, this paper might provide some implications toward the damage of the big earthquake in Tohoku region of Japan. The Tohoku Pacific Earthquake of magnitude 9.0 struck Tohoku region of Japan on March $11^{\text {th }}$ 2011. The earthquake and Tsunami caused extensive and severe damage in Japanese economy as well as production networks in Japanese machinery sectors. Since many plants located in Tohoku region have played a key role in domestic production in Japanese machinery, the destruction of domestic networks might substitute to overseas production, lowering the Japanese border effect more. This is a space for future research.

\section{Acknowledgement}

A previous version of this paper was presented at the Hitotsubashi Conference on International Trade and FDI, December 12-14, 2003, Tokyo, Japan. The authors are grateful for the helpful comments by Elton J.Fairfield, Richard E. Baldwin and anonymous referees. 


\section{References}

Ahn, S., K. Fukao and K. Ito. (2008), The impact of outsourcing on the Japanese and South Korean labor markets: International outsourcing of intermediate inputs and assembly in East Asia, Global COE Hi-Stat Discussion Paper Series 08-015, Hitotsubashi University, Japan.

Anderson. J.E., and E.van Wincoop. (2003), Gravity with Gravitas: A Solution to the Border Puzzle, American Economic Review, 93(1), 170-192.

Anderson. J.E., and E.van Wincoop. (2004), Trade Costs, Journal of Economic Literature, 42(3), 691-751.

Ando, M. and F. Kimura. (2005), The formation of international production and distribution networks in East Asia. In International trade (NBER-East Asia seminar on economics. Vol. 14), edited by T. Ito and A. Rose. Chicago: The University of Chicago Press. First version, NBER Working Paper 10167.

Baldwin, R.E. (2008), "Managing the noodle bowl: The fragility of East Asian regionalism," Singapore Economic Review, 53, 449-478.

Baldwin, R.E., D.Taglioni. (2006), Gravity for dummies and dummies for gravity equations, CEPR Discussion Paper 5850.

Balistreri, E , and R. Hillberry. (2006), Trade Frictions and Welfare in the Gravity Model: How Much of the Iceberg Melts?, Canadian Journal of Economics, 39(1), 247-265.

Dias, D. (2011), "The Border Effect through the Rearview Mirror: Would the puzzle have existed if today's tools had been used?", University of Illinois at Urbana-Champaign, unpublished manuscript.

Eaton, J., and A. Tamura. (1994), Bilateralism and Regionalism in Japanese and U.S. Trade and Direct Foreign Investment Patterns, Journal of the Japanese and International Economies, 8(4), 478-510.

Ekholm, K., and K. Hakkala. (2006), The Effect of Offshoring on Labour Demand: Evidence from Sweden, Research Institute of Industrial Economics, Stockholm, mimeo.

Feenstra, R.C., and G.H. Hanson. (1999), The Impact of Outsourcing and HighTechnology Capital on Wages: Estimates for the United States, 1979-1990, Quarterly Journal of Economics, 114(3), 907-940.

Fukao, K., and H. Chung. (1997), Nihon-kigyo no Kaigai Seisan Katsudo to Boeki Kozo (The Production Activity Abroad by Japanese Firms and Japan's Trade Structure), in K. Asako and M. Ohtaki (eds.), Gendai Macro Dogaku (Modern Macro Economic Dynamics), University of Tokyo Press, Tokyo.

Fukao, K., H. Ishido, and K. Ito. (2003), Vertical Intra-Industry Trade and Foreign Direct Investment in East Asia, Journal of the Japanese and International Economies, 17(4), 469-506.

Fukao, K., G. Kataoka, and A. Kuno. (2005), How to Measure Non-tariff Barriers? A Critical Examination of the Price-Differential Approach, in C.Y. Ahn, I. Cheong, Y. 
Fukagawa, and T. Ito (eds.), Toward a Model Case for East Asian Economic Integration, Korea Institute for International Economic Policy (KIEP), Seoul.

Fukao, K. and X. Yue. (1997), Denki meka no Ricchi Sentaku (Location Choice in the Electronics Machinery Sector), Mita Keizai Zasshi, 90(2), 11-39.

Greaney, T. M. (2005), Measuring Network Effects on Trade: Are Japanese Affiliates Distinctive? Journal of the Japanese and International Economies, 9(2), 194-214.

Itoh, H. (2006), The Theories of International Outsourcing and Integration: A Theoretical Overview from the Perspective of Organizational Economics, JCER Discussion Paper Series No. 96.

Lawrence, R. Z. (1987), Imports in Japan: Closed Markets or Minds? Brookings Papers on Economic Activity, 2, 517-554.

Lipsey, R. E., E. D. Ramstetter, and M. Blomström. (2000), Outward FDI and Parent Exports and Employment: Japan, the United States, and Sweden, Global Economy Quarterly, 1(4), 285-302.

Martin, P., Mayer, T., Thoenig, M., (2007), Make trade not war?, revised version of CEPR Discussion Paper 5218.

McCallum, J. (1995), National Borders Matter: Canada-U.S. Regional Trade Patterns, American Economic Review, 85(3), 615-623.

METI (Ministry of Economy, Trade and Industry, Japan) (2001), Kaigai Jigyo Katsudo Kihon Chosa (Basic Survey of Overseas Business Activities), METI, Tokyo.

MITI (Ministry of International Trade and Industry, Government of Japan) (1999), Keizai Hakusho (White Paper on International Trade), MITI, Tokyo..

Okubo, T. (2004), The Border Effect in the Japanese Market: A Gravity Model Analysis, Journal of the Japanese and International Economies, 18(1), 1-11.

Okubo, T. (2007), Intra-industry Trade, Reconsidered: The Role of Technology Transfer and Foreign Direct Investment, The World Economy, 30(12), 1855-1876.

Rose, A.K., van Wincoop, E., (2001), National money as a barrier to international trade: The real case for currency union, American Economic Review, 91(2), May, 386-90.

Santos Silva, J.M.C., and S. Tenreyro. (2006), The Log of Gravity. The Review of Economics and Statistics, 88, 641-658.

Sazanami Y., S. Urata and H. Kawai. (1995), Measuring the Costs of Protection in Japan, Institute for International Economics, Washington, D.C.

Tomiura, E. (2003), Changing Economic Geography and Vertical Linkages in Japan, Journal of the Japanese and International Economies, 17(4), 561-581. 


\section{Appendix}

Table A. Basic Statistic

\begin{tabular}{|c|c|c|c|c|c|}
\hline Variable & Obs & Mean & Std.Dev. & Min & Max \\
\hline \multicolumn{6}{|l|}{ Electorical } \\
\hline Trade & 3936 & 3.83594 & 4.217748 & 0 & 14.75636 \\
\hline DIS & 3808 & 8.948533 & 0.829946 & 4.231161 & 9.829209 \\
\hline lalongf & 3936 & 0.048638 & 0.20742 & 0 & 2.550981 \\
\hline lagainstf & 3936 & 0.047003 & 0.203916 & 0 & 2.550981 \\
\hline lalongjp & 3936 & 0.111548 & 0.617826 & 0 & 6.434546 \\
\hline lagainstjp & 3936 & 0.111548 & 0.617826 & 0 & 6.434546 \\
\hline \multicolumn{6}{|l|}{ General } \\
\hline Trade & 3936 & 3.488331 & 3.9962 & 0 & 14.41815 \\
\hline DIS & 3808 & 8.948533 & 0.829946 & 4.231161 & 9.829209 \\
\hline lalongjp & 3936 & 0.040721 & 0.153711 & 0 & 1.772067 \\
\hline lalongf & 3936 & 0.038125 & 0.14945 & 0 & 1.772067 \\
\hline lagainstjp & 3936 & 0.129726 & 0.655036 & 0 & 5.934894 \\
\hline lagainstf & 3936 & 0.30552 & 0.830494 & 0 & 4.356709 \\
\hline \multicolumn{6}{|l|}{ Precision } \\
\hline Trade & 3936 & 2.793444 & 4.142638 & 0 & 17.95896 \\
\hline DIS & 3808 & 8.948533 & 0.829946 & 4.231161 & 9.829209 \\
\hline lalongf & 3936 & 0.024225 & 0.149913 & 0 & 2.598885 \\
\hline lagainstf & 3936 & 0.021887 & 0.14304 & 0 & 2.598885 \\
\hline lalongjp & 3936 & 0.063863 & 0.412687 & 0 & 5.164786 \\
\hline lagainstjp & 3936 & 0.063863 & 0.412687 & 0 & 5.164786 \\
\hline \multicolumn{6}{|l|}{ Transport } \\
\hline Trade & 3936 & 3.490384 & 4.095092 & 0 & 14.95956 \\
\hline DIS & 3808 & 8.948533 & 0.829946 & 4.231161 & 9.829209 \\
\hline lalongf & 3936 & 0.031065 & 0.152533 & 0 & 2.180337 \\
\hline lagainstf & 3936 & 0.031351 & 0.152901 & 0 & 2.180337 \\
\hline lalongjp & 3936 & 0.086487 & 0.503268 & 0 & 5.164786 \\
\hline lagainstjp & 3936 & 0.086487 & 0.503268 & 0 & 5.164786 \\
\hline
\end{tabular}


Table B. List of Foreign Countries

\begin{tabular}{lllll}
\hline Australia & Cyprus & Italy & Norway & Spain \\
Austria & Denmark & Jordan & Panama & Sweden \\
Bangladesh & Ecuador & Korea & Peru & Switzerland \\
Bergium & Fiji & Kuwait & Philippines & Thailand \\
Bolivia & Finland & Malaysia & Portugal & Tunisia \\
Canada & France & Malta & Romania & Turkey \\
SriLanka & Germany & Mauritius & Russia & Egypt \\
Chile & Greece & Mexico & Saudi & UK \\
China & Iceland & Nepal & Senegal & USA \\
Colombia & India & Netherlands & Singapore & Venezuela \\
Costarica & Indonesia & NewZealand & South Africa & Zimbabwe \\
\hline
\end{tabular}

